DOI: 10.17707/AgricultForest.63.1.30

\author{
Sabina DELIĆ, Ljiljana KEČA, Aida IBRAHIMSPAHIĆ, \\ Azra C̆ABARAVDIĆ and Damir BEHLULOVIĆ ${ }^{1}$
}

\title{
VALUE CHAIN ANALYSIS OF NON-WOOD FOREST PRODUCTS IN FUNCTION OF SUSTAINABLE DEVELOPMENT OF FOREST RESOURCES AND RURAL DEVELOPMENT IN BOSNIA AND HERZEGOVINA
}

\begin{abstract}
SUMMARY
Forest resources in Bosnia and Herzegovina present rich sites of various non-wood forest products. In the concept of sustainable use of forest resources and assurance the economic, environmental and social effects, non-wood forest products have great importance, especially in the strategic commitments of rural development. However, information on the potentials of non-wood forest products in Bosnia and Herzegovina is very scant, whereas institutional and procedural framework relevant to this sector is underdeveloped. In this paper value chain analysis of non-wood forest products in Bosnia and Herzegovina have been carried out in order to identify the participants in the value chain, their mutual relations, and the analysis of organizational and institutional issues that affect the economic aspects of certain stages of the value chain. Survey method was used for primary data collection in the Federation of Bosnia and Herzegovina, where the relevant information from participants in the chain of non-wood forest products has been obtained. The study included a sample of 156 collectors, who had continuity in the collection and delivery, and 18 companies engaged in purchasing, processing and distribution, which have agreed to participate in the research. For data processing and interpretation of the results classical methods of analysis, synthesis, induction, deduction and comparison, and statistical methods of trend analysis were used. Technique of SWOT analysis was used in order to identify the positive and negative factors, as the basis for defining the strategic direction of non-wood forest products sector development.

The obtained results indicate on the presence of numerous problems in the value chain. The share of individual groups of non-wood forest products in the analyzed period is: $50 \%$ of berries, $40 \%$ of medicinal and aromatic plants and $10 \%$ of mushrooms. The average annual growth rate of purchased and processed amounts of medicinal and aromatic plants was 17\%, $28 \%$ of forest berries, and
\end{abstract}

\footnotetext{
${ }^{1}$ Sabina Delić (corresponding author: sabinadelic@yahoo.com), Aida Ibrahimspahić, Azra Čabaravdić, Faculty of Forestry University of Sarajevo, Zagrebačka street 20, 71000 Sarajevo, BOSNIA AND HERZEGOVINA; Ljiljana Keča, University of Belgrade, Faculty of Forestry, Kneza Višeslava street 1, 11030 Belgrade, SERBIA; Damir Behlulović, Federal Office of Agropedology, Dolina street 6, 71000 Sarajevo, BOSNIA AND HERZEGOVINA
} 
$34 \%$ of mushrooms. Approximately $93 \%$ of these products are distributed in the international market, whereas achieved prices are twice as high as compared to the domestic market. Sales trend has been increasing both in the domestic and foreign markets. The average annual growth rate of sales in the domestic market for mushrooms is $120 \%$, for forest berries $85 \%$, and for medicinal and aromatic plants $64 \%$. The average annual growth rate of sales in foreign markets is $15 \%$ for medicinal and aromatic plants, $26 \%$ for berries and 33\% for mushrooms. The most important foreign markets are Germany, Italy and Austria, and also the United States and Canada for essential oils. The research results show that it is necessary to take certain measures on improvement the institutional and procedural framework relevant for the sector of non-wood forest products, for purpose of its affirmation and contribution to overall national economy. Observed in a broader socio-economic context, it can significantly affect the definition of the forest policy objectives, multifunctional use and determining the strategic direction of sustainable forestry development.

Keywords: non-wood forest products, value chain, sustainable development of forest resources, rural development, Bosnia and Herzegovina

\section{INTRODUCTION}

In recent decades, worldwide interest and demand for healthy food and organic products is increasing. Different non-wood forest products (hereinafter NWFPs) belong to this group of products since they meet the criteria of organic production. Many important international organizations (FAO, World Bank, CIDA, IDRC, CIFOR, IUCN) have NFWPs in its research portfolio and promote their importance. There are different definitions of NWFPs proposed by many authors (Arnold, 1995; Chamberlain et al. 1998), but in general practice universally accepted definition is proposed by FAO, by which the NWFPs all products are goods of biological origin other than wood derived from forest, other wooded land and trees outside forests (FAO, 2008). It includes: medical, edible and aromatic herbs, mushrooms, berries, honey, resin, moss, peat and similar (Pettenella et al., 2006; Adepoju, Salau, 2007).

In the concept of forest resources sustainability and sustainable development of the forestry sector, NWFPs have great importance. Economic, environmental and social effects of the NWFPs use are undisputed, but they are, even in the most developed countries, still insufficiently known. The reason for this is, above all, the lack of data on the quantities and quality of collected and distributed products (Turtiainen, Nuutinen, 2012). For successful commercialization of NWFPs it is necessary to be aware of the available potential, as well as the factors and constraints that affect the usage (Keča, 2015). The commercialization of the NWFPs have been widely promoted as a concept in the rural development approach, poverty alleviation and conservation of natural resources (Schreckenberg, K. et al., 2006). NWFPs as raw materials are linked to final consumers through a chain of value creation, whose optimization can 
contribute to more efficient production of these products, global markets access and improvement of competitiveness (Keča, Lj. et al., 2013).

Bosnia and Herzegovina (hereinafter B\&H), together with other countries of Southeast Europe (Albania, Montenegro, Croatia, Macedonia and Serbia), constitute a key area for NWFPs collection, which plays important role in the local, regional and international trade (FAO, 2010). Based on various reports on NWFP potentials (Tanović, 2011; LAMP, 2004; FARMA, 2010), it is estimated that $\mathrm{B} \& \mathrm{H}$ has $200-300$ plant species in nature, which are treated as medicinal, edible and aromatic (Vojniković et al., 2013). More precise data on NWFPs potentials in $\mathrm{B} \& \mathrm{H}$ does not exist, whereas the institutional and procedural framework, relevant to this sector, is underdeveloped. In the most cases actors of the NWFP sector in $\mathrm{B} \& \mathrm{H}$ show professional and organizational weaknesses, which impede the achievement and maintenance of competitive stability (Behlulović, 2015). The participants of the NWFP value chain (collectors, buyers and processors) in business philosophy are distant from each other, without regulated long-term relationships and a sufficient knowledge of market opportunities.

In recent years, a significant increase in exports of the NWFPs from B\&H has been recorded, mainly raw materials, while the share of processed substances have been negligible. Estimates on NWFP values export in the Federation of $\mathrm{B} \& \mathrm{H}$ (hereinafter $\mathrm{F} \mathrm{B} \& \mathrm{H}$ ) are ranging from 14 to 15 million $€$ per year, with an annual growth rate of $7-10 \%$ (Foreign Trade Chamber of B\&H). It is also estimated that annualy from natural population in the F B\&H $1800 \mathrm{t}$ of dried plant material and mashrooms have been collected, of which $95 \%$ are exported, while the plantation amounts of medicinal and aromatic plant species are negligible (Behlulović, 2015. according to Tanović, 2014). Global demand trend for medicinal and aromatic herbs and mushrooms is increasing, which gives the opportunity for access to the new markets. The NWFP value presents a significant component to the forest ecosystems value, which can affect the changes in the forest management practice. These are positive signals to the forest users (forest management companies) for rational and sustainable use of all available resources (Delić \& Pozderac, 2011a). In that sense, forest owners (private and public) must be able to recognize the economic effects of their use or custom businesses for the purpose of providing these products and services. This creates presumptions and possibilities for development of small and medium entrepreneurship, which can stimulate economic development of rural areas, especially areas with agrravated living conditions. Sustainable use of NWFPs is the most direct and the most profitable method of linking the use and conservation of forests (Peters et al.,1989).

The results of this research have theoretical and practical significance and can contribute to the sustainable development of the NWFP sector, and thus forestry as bussines (Delić et al., 2011b). 


\section{MATERIAL AND METHODS}

The research was conducted within the entity of the $\mathrm{F} \mathrm{B \& H}$, which takes $51 \%$ of the total area of $\mathrm{B} \& \mathrm{H}$. Forests and forest lands of $\mathrm{F} \mathrm{B \& H}$, as sites of NWFPs, occupy an area of 1518600 hectares (Ministry of spatial planinng of $F$ $\mathrm{B} \& \mathrm{H}, 2012)$. In certain phases of research, methods of analysis, synthesis, induction, deduction and comparation were applied. For the analysis of NWFP value creation chain, overall value chain was breakdown to the relevant sections or stages, which start from collection of the basic raw materials, purchase, procession, transportation, to placement for the end-users.

Using the technique of interviewing, primary data were collected for the period from 2010 to 2014 . For that purposes two types of the questionnaire were created, one for collectors and other for processors (legal entities), whose primary business is related to NWFP. The questionnaire was modified according to Keča et al., (2013).

In the $\mathrm{F} B \& \mathrm{H}$ there is no register on collectors, therefore their total number is not known (Behlulović, 2015). This study includes a sample of 156 collectors, whereas the criteria for selection were: continuity in the collection and delivery of NWFPs, and territorial distribution. Questionnaire for collectors included questions related to socio-demographic profile, the basic aspects of NWFPs collecting (realized revenue, structure and volume of the collection, quality, conditions and problems in the collection, ownership of equipment, organization of collecting and collectors' education, membership in associations of collectors), and market aspects and factors that affect the purchase price.

Questionnaire for processors was consisted of several groups of questions which, in addition to socio-demographic profile processors, provided the following information: owning and utilization of capacites for NWFPs finishing and processing, structure and participation in the processing of certain types of NWFPs, purchase and transport, business environment and cooperation with other companies, market etc. In the F B\&H 20 small and medium enterprises in the private property has been registered which belongs to the Group for herbs and berries within the Foreign Trade chamber of B\&H (GEA, 2012). The survey included 18 companies that have given consent to participate in the research.

Statistical method of trend analysis was used in the addressing collected data, whereby the tendencies for development of purchase, finishing and processing of the considered NWFP types in the analyzed period were presented by a linear trend. In addition to the size of parameters functions trend, the size of the determination coefficient was determined as well, and also standard and relative errors of trend as a measure of estimation accuracy and quality assessment (Somun-Kapetanović, 2006). Based on the chain index the average annual growth rate of the observed sizes for the stages of collection, purchase, processing and sales was determined.

Technique of SWOT analysis was used for identication of positive and negative factors that present basis for defining the strategic direction of NWFP sector development and the setting of priorities in the strategic planning. 


\section{RESULTS AND DISCUSSION}

\section{The characteristics of the NWFP value chain in the F B\&H}

The participants in the value chain and key actors in the implementation of these activities are collectors, buyers and processors, who have an important impact on the NWFP value chain and have the opportunity to contribute in increasing the efficiency and effectiveness of production in this sector, and as well increase competitiveness in the global market. Three groups of NWFP were analyzed: medicinal and aromatic plants, forest berries and mushrooms for all relevant segments. The chain of activities from procurement to usage of the NWFPs is quite complex and influenced by many factors (Sheme 1).

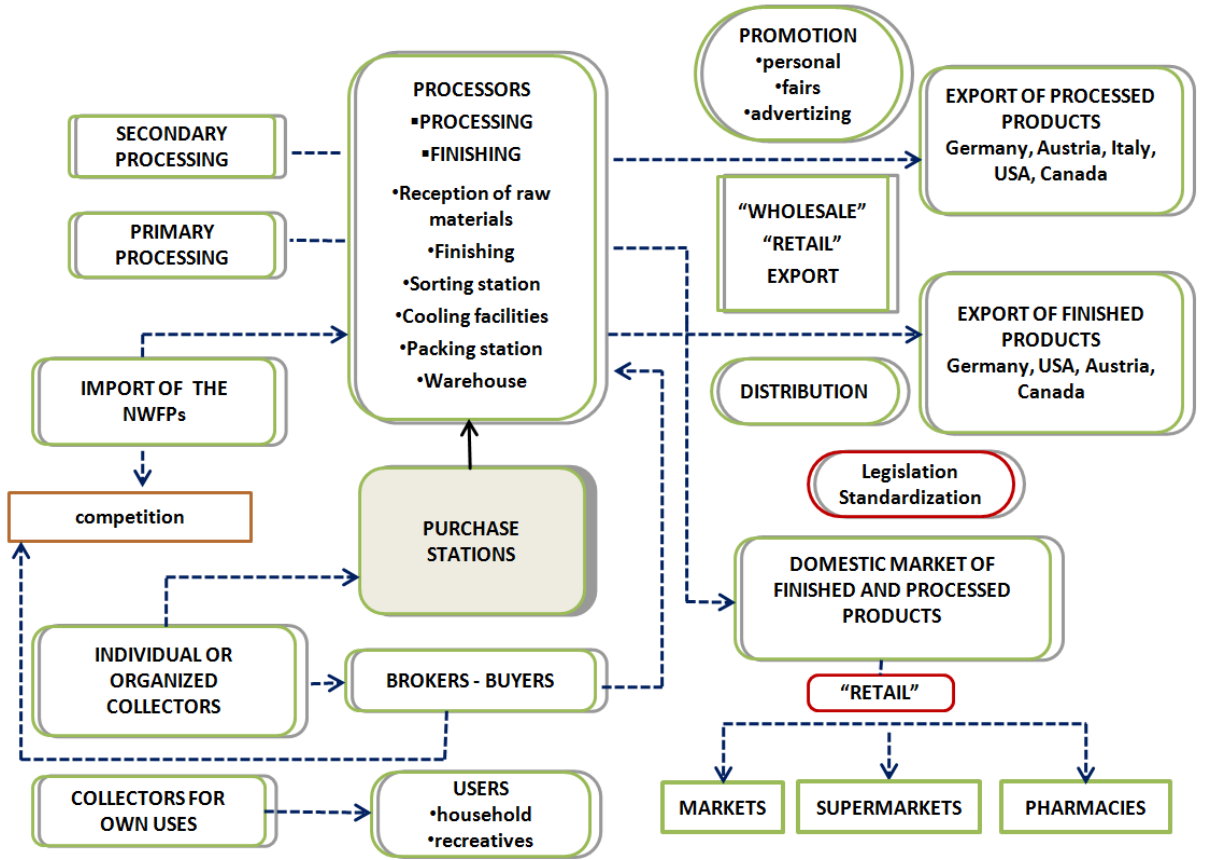

Sheme 1. NWFP value chain in the F B\&H

Collectors of NWFP in F B\&H form the largest group of participants of chain that from natural populations (forest resources) collect NWFPs in its original form. Their contribution to the creation of additional and the total value is quite modest, because the collected products are usually sold as a raw material (pure substance) or just some primary form of processing is done (e.g., drying). They are a heterogeneous group, which aggravates their organization and realization of common goals. Of the total number of interviewed collectors, over $60 \%$ belong to the age category of $25-45$ years, whereas $20 \%$ is younger than age 25. Most collectors belong to rural and unemployed population, out of which over $60 \%$ are female with elementary or secondary education. For the $44 \%$ of collectors NWFPs are the main source of income, for $38 \%$ additional, and rest 
engaged collect NWFP for their own consumption. About $70 \%$ of the collectors believe that collected NWFPs are high quality, whereas only $4 \%$ assessed quality as bad. Problems that collectors highlight are mainly related to low prices, unfairness of purchasers and time-consumption. The largest number of respondents $(34 \%)$ ween that the costs of the raw materials are low, and that in the NWFP value chain there is no equitable distribution among the participants, which in facts always negatively affect the collectors. About $26 \%$ of respondents pointed out the problem of time-consuming for collecting, $20 \%$ think that buyers are not fair, while $16 \%$ think that there are no enough raw materials, because the collection is not carried out in a sustainable way, which results in reducing the spots of some species (e.g. blueberries and cranberries).

Majority of interviewed collectors $(82 \%)$ does not hold equipment for collecting and picking of the NWFPs, and those who possess, very rarely used it. Most collectors (85\%) do not have knowledge about the basic principles and methods for identifying species, rules and modes of sustainable collection and other procedures related to this issue. Only $15 \%$ of the collectors comply with the rules of good collection practice. The collection of NWFPs is mainly unorganized, and only $17 \%$ of collectors carried out these activities with organized manner under the supervision of buyers (processors). About 63\% of the collectors have not attended any training concerning the collection of NTFPs, while other hold certificate for successfully completed training on identifying and collecting medicinal and aromatic plants and mushrooms. The largest number of interviewed (80\%) do not have membership in any association of collectors, 5\% are members of the Association of citizens for medicinal and aromatic plants, mushrooms and their production of $\mathrm{F} \mathrm{B \& H}$, and the rest belong to some of the municipal or cantonal non-governmental organizations.

Purchase and processing of NWFPs in the F B\&H for the most cases takes place within the small businesses that are privately owned and still under development. Analysis of the processors socio-demographic profile indicates that the average age is 44 years, with the dominant representation of males $(78 \%)$. About $45 \%$ of managers in surveyed companies have a master degree, $22 \%$ bachelor degree, and 33\% secondary school education.

The available facilities for reception of the raw materials, storage, processing and finishing, as well as equipment, are not in accordance with the needs of processors, and do not meet basic standards. Only three of processing capacities fulfill all necessary requirements and standards for certification. Three processors have distilleries for distillation of the medicinal and aromatic plants and evergreen needle trees. Only two processors have cooling facilities and laboratory for their own basic analysis. About $90 \%$ of raw materials have been purchased directly from collectors in narrower and wider areas of the $\mathrm{F} \mathrm{B \& H}$, and the rest through the purchase stations and brokers.

Over $70 \%$ of surveyed companies tweak purchased raw materials, while others also process it. At the level of F B\&H there are no installed capacities for processing of mushrooms, although in some companies there are concrete ideas 
and initiatives. Purchased amounts of mushrooms processors subject to the aspects of necessary tweaks, which refers to the drying, freezing, brining and the like. Although yield and quality of NWFPs largely dependent on natural and weather conditions, only $18 \%$ of respondents believe that this is the main influencing factor on prices. About $30 \%$ said that wholesales affect to the price fluctuations, buyers (28\%) and processors (24\%).

It is important to note that about $95 \%$ of processors did not signed a contract on the use of resources, thus they should be paying compensation for the use of resources.

The amount and structure of purchased NWFPs in the analyzed period was different per years. The share of forest berries is the highest (about 50\%) on annual average, medicinal and aromatic plants about $40 \%$ and mushrooms about $10 \%$ (Table 1). The average annual growth rate of purchased and processed amount of medicinal and aromatic plants was $17 \%$, forest berries $28 \%$ and mushrooms $34 \%$.

Table 1. Structure and amount of the purchased raw materials for the period 2010-2014

\begin{tabular}{|c|c|c|c|c|c|c|}
\hline \multirow{2}{*}{ NWFP } & \multicolumn{5}{|c|}{ Amount (t/year) } & \multirow{2}{*}{$\begin{array}{c}\text { The average } \\
\text { annual growth } \\
\text { rate }(\%)\end{array}$} \\
\hline & 2010 & 2011 & 2012 & 2013 & 2014 & \\
\hline $\begin{array}{l}\text { Medicinal and } \\
\text { aromatic plants }\end{array}$ & 591 & 686 & 870 & 978 & 1101 & 17 \\
\hline Forest berries & 577 & 890 & 1229 & 1272 & 1449 & 28 \\
\hline Mushrooms & 103 & 141 & 211 & 268 & 329 & 34 \\
\hline
\end{tabular}

17 surveyed companies operate with purchasing and processing of medicinal and aromatic plants, whereas over $70 \%$ of total production is covered by the three large companies. The market most interesting medicinal and aromatic plant species are: wild garlic (Allium ursinu L.), hawthorn (Crataegus monogyna L.), mistletoe (Viscum album L.), Iceland moss (Cetraria islandica L.), sage (Salvia officinalis L.), juniper (Juniperus communis L.), silver linden (Tilia tomentosa L.), curry plant (Helichrysum italicum L.).

About $80 \%$ of the surveyed companies operate with finishing and processing of forest berries, whereas over $75 \%$ of production is concentrated in three large companies. Ten companies operate with buying and processing of the mushroom, whereas over $80 \%$ of production takes place in four companies. The market most interesting species from the group of forest berries are: blueberry (Vaccinium myrtillus L.), cowberry (Vaccinium vitis idaea L.), woodland strawberry (Fragaria vesca L.), dog-rose (Rosa canina L.), blackthorn (Prunus spinosa L.), and from the group of mushrooms are: porcini (Boletus edulis L.), chanterelles (Cantharellus cibarius L.), morel (Morchella conica L.), Caesar's mushroom (Amanita caesarea L.), fairy ring mushroom (Marasmius oreades L.). 
In the analyzed period, trend of purchasing, finishing and processing of all types of the NWFPs has been growing (Figure 1). Identified linear trends for all three categories of NWFPs are characterized by a high coefficient of determination ( $93 \%$ or $99 \%$ ), whereas the relative error of the estimate is 2.1 to 7.4\%. The quality of these trends, given the determined size of estimation accuracy indicators and quality assessment is quite good or very good (SomunKapetanović, 2006).

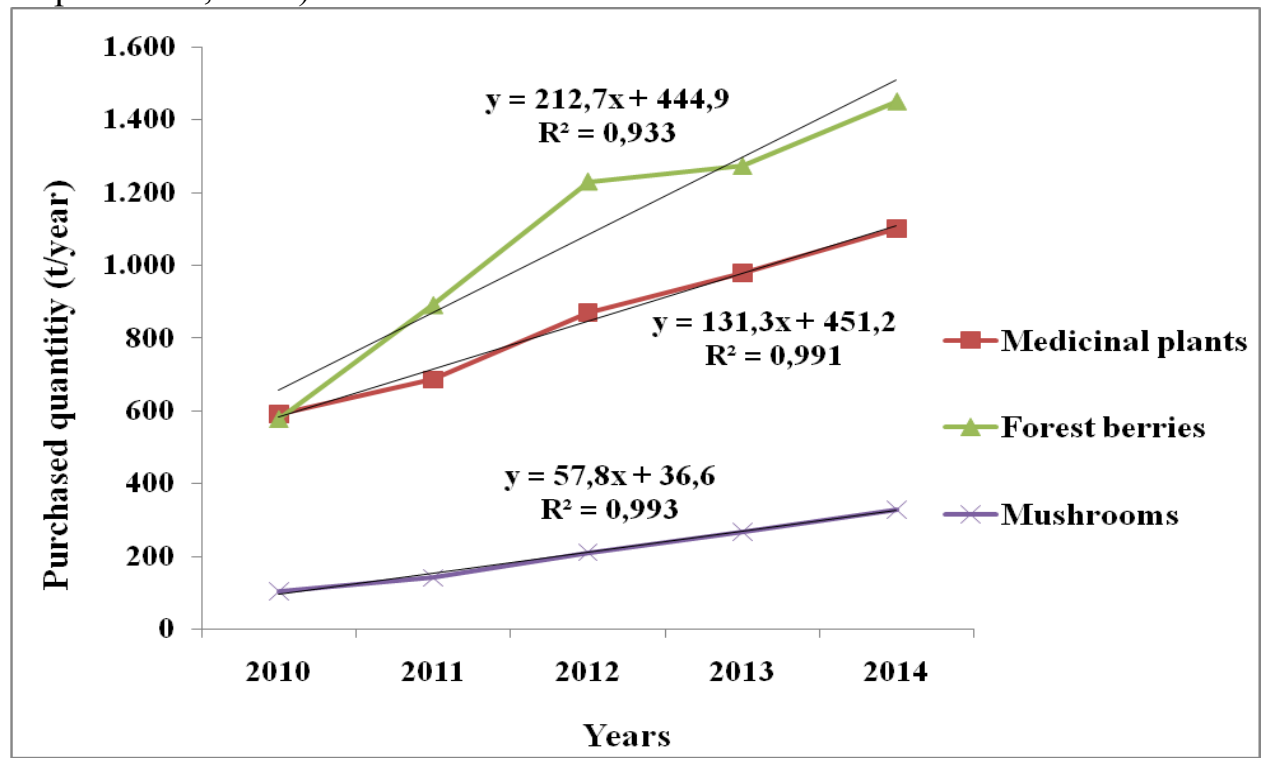

Figure 1. The trend of purchasing, finishing and processing of NWFPs for the period 2010-2014

\section{Placement directions of NWFP}

Approximately 93\% of NWFPs are distributed to the international market, and majority of surveyed representatives of processors (78\%) are not interested in the domestic market, due to low prices, low demand and uncertainty of business.

Market of the NWFPs in the F B\&H is strongly influenced by the gray market (unregistered collection and transport), which has a negative impact on relations between collectors and purchasers/processors, with the presence of distrust and unfair competition. Their mutual relations usually are not regulated by contract, thus collectors are free in choosing purchasers, and this has an impact on the purchase prices and stability in the supply of raw materials. The largest quantity of products that have been traded in the domestic market are medicinal and aromatic plant species, then forest berries and least mushrooms (Table 2). The domestic market of medicinal and aromatic plants in B\&H is still under development, and as end products, being sold in the domestic market, are mainly mono-component teas, tea mixtures, cosmetic, tinctures, drops, capsules etc. 
Table 2. Sale of NWFPs in the domestic market for the period 2010-2014

\begin{tabular}{|l|c|c|c|c|c|c|}
\hline \multirow{2}{*}{\multicolumn{1}{|c|}{ NWFP }} & \multicolumn{4}{|c|}{ Amount (t/year) } & \multirow{2}{*}{$\begin{array}{c}\text { The average annual } \\
\text { growth rate (\%) }\end{array}$} \\
\cline { 2 - 6 } & $\mathbf{2 0 1 0}$ & $\mathbf{2 0 1 1}$ & $\mathbf{2 0 1 2}$ & $\mathbf{2 0 1 3}$ & $\mathbf{2 0 1 4}$ & \\
\hline $\begin{array}{l}\text { Medicinal and } \\
\text { aromatic plants }\end{array}$ & 16 & 25 & 58 & 76 & 104 & 64 \\
\hline Forest berries & 12 & 15 & 49 & 65 & 101 & 85 \\
\hline Mushrooms & 3 & 3 & 15 & 21 & 26 & 120 \\
\hline
\end{tabular}

And despite the small quantity and low share of the domestic market in sales of the NWFPs, an extremely high growth rate of sales for all products in the analyzed period have been achieved. The highest average annual growth rate of sales in the domestic market is for mushrooms (120\%), for forest berries $85 \%$ and for medicinal and aromatic plants $64 \%$.

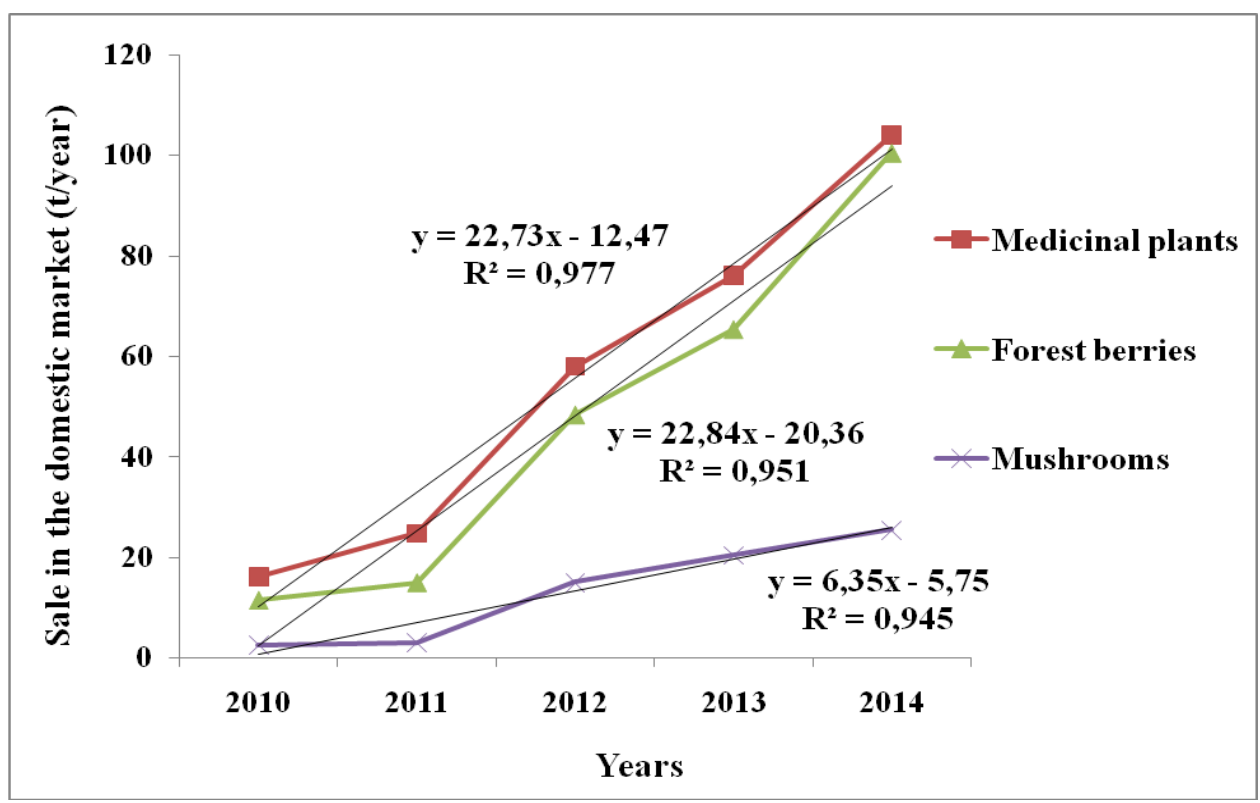

Figure 2. Sales trend of NWFPs in the domestic market for the period 2010-2014

The established linear growth trends are characterized by a high coefficient of determination (94-97\%), whereas the relative error of the estimate is 8.8 to $16.2 \%$, which indicates the quite good and very good quality evaluations of these trends (Figure 2).

The export trend of NWFPs has been also growing with the lower growth rate compared to the domestic market. Pure finished substance was mainly exported, whereas lower share refers to distillates of medicinal and aromatic 
plants. In total exported quantities of the NWFPs for the period 2010-2014 participation of forest berries is over $50 \%$, medicinal and aromatic plants about $40 \%$ and mushrooms about $10 \%$ (Table 3 ).

Table 3. Sale of NWFPs in the international market for the period 2010-2014

\begin{tabular}{|l|c|c|c|c|c|c|}
\hline \multirow{2}{*}{ NWFP } & \multicolumn{5}{|c|}{ Amount (t/year) } & \multirow{2}{*}{$\begin{array}{c}\text { The average annual } \\
\text { growth rate (\%) }\end{array}$} \\
\cline { 2 - 6 } & $\mathbf{2 0 1 0}$ & $\mathbf{2 0 1 1}$ & $\mathbf{2 0 1 2}$ & $\mathbf{2 0 1 3}$ & $\mathbf{2 0 1 4}$ & 15 \\
\hline $\begin{array}{l}\text { Medicinal and } \\
\text { aromatic plants }\end{array}$ & 568 & 652 & 814 & 905 & 1000 & 26 \\
\hline Forest berries & 561 & 872 & 1184 & 1210 & 1354 & 33 \\
\hline Mushrooms & 100 & 136 & 197 & 248 & 305 & 5 \\
\hline
\end{tabular}

The sale trend in the international market has been growing with an average annual growth rate of $15 \%$ for medicinal and aromatic plants, $26 \%$ for forest berries and 33\% for mushrooms. Linear exports trends for all categories of the NWFPs are characterized by the high coefficient of determination (91-99\%) (Figure 3).

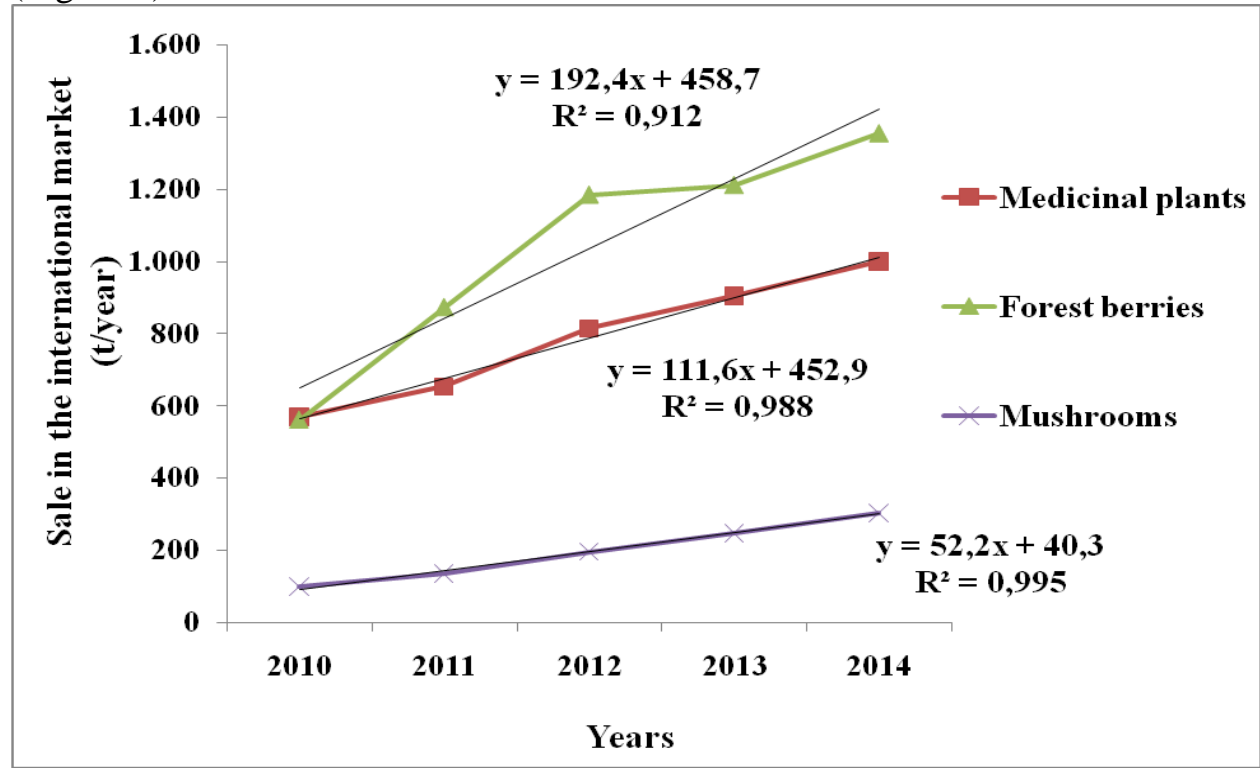

Figure 3. Sale trend of the NWFPs in the international market for the period 2010-2014

The relative error of the estimate ranges from 2.1 to $8.2 \%$, which indicate a very good evaluation of trends quality and estimation accuracy of tendency. The largest amount of all types of the NWFPs are exported to Germany, then Italy and Austria, while the essential oils are placed to USA and Canada market. The trend of exports increase of these products for the analyzed period in all foreign markets has been growing (Figure 4). 

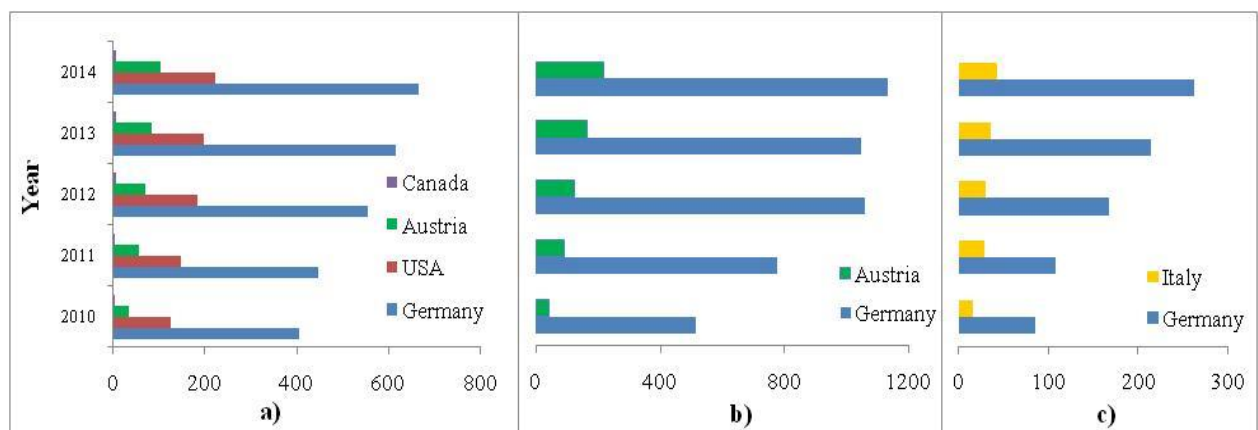

Figure 4. Export of NWFPs (t) by placement directions for the period 2010-2014: a)medicinal and aromatic plants; b) forest berries; c) mushrooms

\section{Prices and promotion of NWFPs}

Prices of all product categories in the NWFP value chain were different for the analyzed period, whereas the lowest share in the value chain has collectors. The majority of surveyed collectors believe that the purchase prices are low, while purchasers think that prices are fair.

Only $22 \%$ of purchasers believe that collectors should have a larger share in the NWFP chain. Market prices of all analyzed species are 2-3 times larger (even 10 times for some species of mushroom) in relation to the purchase price, which indicates on a high trade margins in the value chain, as well as the inadequate distribution of values within the value chain. Average realized prices of NWFPs in the domestic market were about twice lower compared to the prices in the international market.

The basic promotion method for the majority processors takes place through direct contact, or at the fairs, and it applies via advertising through a web presentations and advertising pamphlets. Approximately $67 \%$ of processors are certified by HACCP system, and/or certified by Organic Food Standard system.

\section{Analysis of internal and external factors (SWOT analysis)}

Based on the analysis and obtained information regarding the NWFPs, matrix for segments of purchase, processing and distribution of NWFPs have been formulated in which was reviewed the internal and external factors that directly affect the NWFP chain (Table 4). The results of internal strengths and weaknesses analysis, and external opportunities and threats, can serve as good basis for defining strategic development of this sector.

Based on the evaluation of certain internal and external influence factors on the NWFP chain strategy for development of NWFP sector in the F B\&H can be defined, which should be built based on the maximum use of internal strength of the NWFP sector, with as much as possible use of the possibilities from the environment. The maximal internal strengths are reflected in the great wealth and diversity of the NWFPs, high-quality of raw materials, and competitiveness on the international market. The opportunities which should be used are in increased demand for the NWFPs, investing in processing capacities and increasing the 
level of processing, better cooperation and improvement of relations of participants in NWFP chain, increase product sales in the domestic market and entering new markets, and the use of potential sources of funding for sustainable use of natural resources.

Table 4. Internal and external factors in the sector of NWFPs - SWOT Analysis

\begin{tabular}{|l|l|}
\hline \multicolumn{1}{|c|}{ STRENGHTS } & \multicolumn{1}{c|}{ WEAKNESSES } \\
\hline $\begin{array}{l}\text { The great wealth and diversity of the } \\
\text { NWFPs }\end{array}$ & $\begin{array}{l}\text { Lack of associations of collectors and } \\
\text { skilled labor }\end{array}$ \\
\hline $\begin{array}{l}\text { The quality of raw materials at a high } \\
\text { level }\end{array}$ & $\begin{array}{l}\text { Insufficient utilization of processing } \\
\text { capacities }\end{array}$ \\
\hline Acceptance of standardization & Outdated equipment \\
\hline $\begin{array}{l}\text { Competitive prices and quality of } \\
\text { products }\end{array}$ & $\begin{array}{l}\text { Insufficient financial inputs for } \\
\text { incentives to the rural areas }\end{array}$ \\
\hline Good export potential & The low level of processing \\
\hline Profitable business & $\begin{array}{l}\text { Lack of information on market } \\
\text { opportunities }\end{array}$ \\
\hline $\begin{array}{l}\text { The possibility of plantation production } \\
\text { of certain NWFP }\end{array}$ & $\begin{array}{l}\text { Inadequate system of collection points } \\
\text { and transport of the NWFPs }\end{array}$ \\
\hline The availability of low cost labor & Lack of marketing activities \\
\hline Increased demand for the NWFPs & $\begin{array}{l}\text { The existence of a "gray market" and } \\
\text { unfair competition }\end{array}$ \\
\hline $\begin{array}{l}\text { Better cooperation and relations } \\
\text { between participants in the NWFP chain }\end{array}$ & The lack of state support \\
\hline Adequate training of the workforce & Climate changes \\
\hline $\begin{array}{l}\text { The increase of the product sale in the } \\
\text { domestic market }\end{array}$ & $\begin{array}{l}\text { Problems in export - Customs } \\
\text { Procedures }\end{array}$ \\
\hline Conquering of a new markets & Violation of biodiversity \\
\hline $\begin{array}{l}\text { Investment in processing capacities and } \\
\text { increment of the level of processing }\end{array}$ & $\begin{array}{l}\text { Strong competition in the international } \\
\text { market }\end{array}$ \\
\hline The use of pre-accession funds & Lack of legislation \\
\hline $\begin{array}{l}\text { The introduction of new product lines } \\
\text { and new products }\end{array}$ & \\
\hline
\end{tabular}

\section{CONCLUSIONS}

$\mathrm{B} \& \mathrm{H}$ has a great potential, wealth, diversity and distribution of the NWFPs, but this sector is underdeveloped and disorganized. The whole system is very sensitive to weather conditions, market factors, characteristics of the participants in the chain, the business environment, as well as horizontal and vertical integration within the value chain of all stakeholders.

Collectors and processors recognize the economic importance of the NWFPs as well as the environmental and social aspects, evaluating them as very important, especially in the rural areas. Many problems and conflicts in relationships 
between collectors and buyers are evident, and some of them are: unsatisfactory quality of the product due to poor procedures and rules in collection, insufficient training and professionalism of collectors, poor organization of purchase and transport of collected NWFPs, and dissatisfaction with the distribution of the value in the NWFP value chain. The lowest value gain collectors (two to three times less than the processors), while the share of trade margins in the market prices is very high.

The level of knowledge in the procedures for all participants in the value chain is very low. Impact of processors on collectors for the selection of appropriate methods for sustainable collecting and good "collection practices" is minimal, which is a major threat to break in an integrated value chain. Therefore, it is necessary to provide education to all participants in the value chain in order to facilitate their effective networking and the establishment of partnerships.

Processing of the NWFPs is mainly primary and refers to the phases of drying and freezing, whereas only a small part relates to the production of the essential oils. Capacity building for processing with higher degree of finalization would influence the creation of higher value for all participants in the value chain, whereas encouraging entrepreneurship would have positive effects on rural development and poverty reduction.

There is an evident growing sale trend of all the NWFP types. The basis for achieving competitiveness in international markets is improvement of the technical and technological aspects in proceedings with the NWFPs, standardization and certification, development of the new products, and implementation of marketing activities, in order to provide transparent information on market opportunities for all participants in the value chain.

The legal regulation of this field in accordance with international conventions and regulations on sustainable use and protection of endangered species, and the establishment of monitoring, would have resulted in the conservation of biodiversity and the sustainable use of the NWFPs.

Finally, it should be noted importance of improvement the institutional and procedural framework relevant for the NWFP sector in B\&H with the aim for its affirmation and contribution to the overall national economy. The NWFPs represent a significant part of the forest ecosystems values, and thus can be a driver of development and motivation for change in the concept of the use of forest resources. Seen in a broader socio-economic context, it can significantly affect the definition of the forest policy objectives, multifunctional use and determine the strategic direction of the sustainable forestry development.

\section{REFERENCES}

Adepoju, A. A., Salau, A.S. (2007): Economic valuation of non-timber forest products (NTFPs). (Available at: http://mpra.ub.uni-muenchen.de/2689/), access, 20.09.2016.

Arnold, J.E.N. (1995): Socio-economic benefits and issues in non-wood forest products use, Non-wood forest products 3, FAO, Rome: 89-123.

Behlulović, D. (2015): Value chain and economic potential of non-wood forets products in the Federation of Bosnia and Herzegovina, Master thesis, Faculty of Forestry University of Sarajevo 
Chamberlain, J.L.; Bush R.J.; Hammett A.L. (1998): Non-timber forest products: The other forest products. Forest Product J.48 (10):2-12.

Delić, S., Pozderac, M. (2011a): Value of forests and forest lands, Final report of the Study, Federal Ministry of Agriculture, Water management and Forestry (http://fmpvs.gov.ba/)

Delić, S., Pružan, E., Pozderac, M., Bajrić, A. (2011b): Planning, economics and marketing of forestry business, Final report of the Study, Federal Ministry of Agriculture, Water management and Forestry (http://fmpvs.gov.ba/)

FAO (2008): An Information Bulletin on Non-Wood Forest Products. Non-Wood News, FAO, Vol 17, Rome, pp. 12-21

FAO (2010): Report on Expert Consultation "Institutional Needs for Sustainable NonWood Forest Product Sector in South-East Europe". Food and Agriculture Organization of the United Nations and TRAFFIC International, Budapest, 2010, p.18.

FARMA (2010): Medicinal and aromatic plants in Bosnia and Herzegovina, Project on improvement of agricultural markets, USAID, SIDA (Report)

GEA (2012): Biodiversity conservation through the opening of "green" jobs in the agriculture and forestry sectors, Study, 2012, (http://www.gea.ba/wp-content/)

Keča, Lj., Keča, N., Marčeta, M. (2015): Non-wood forest products, Socio-economics and ecologic aspects, University of Belgrade Faculty of Forestry, Belgrade (ISBN 978-86-7299-232-8)

Keča, Lj.; Keča, N.; Rekola, M. (2013): Value chains of Serbian non-wood forest products - International Forestry Review Vol.15 (3), (315-335), (ISNN 14655489)

LAMP (2004): Medicinal and aromatic plants - Market profile and report on competitiveness, Project - Linking farmers with market, USAID, ARD Inc. (Report)

Marshall, E., Newton, A.C., Schreckenberg, K., (2003), Commercialising non-timber forest products: Factors influencing success. International Forestry Review 5

Peters, C.M., Gentry, A.H., Mendelsohn, R.O. (1989): Valuation of an Amazonian. Forest Nature 339:655-656

Pettenella, D., Ciccarese, L., Dragoi, S., Hegedus, A., Hingston, A., Klöhn, S., Matilainen, A., Posavec, S., Thorfinnsson, T. (2006): NWFP\&S marketing: Lessons learned from case studies in Europe.In: NISKANEN, A. Issues affecting enterprise development in the forest sector in Europe. University of Joensuu, Faculty of Forestry. Research Notes 169: 367-403.

Foreign trade chamber of Bosnia and Herzegovina (2012): Available at: http://www.komorabih.ba/

Schreckenberg, K., Marshall, E., Newton, A., te Velde, D. W., Rushton, J., Edouard, F. (2006): Commercialisation of Non-Timber Forest Products: What Determines Success?, Forestry Briefing Number 10, March 2006, ODI /Overseas Development Insistute, London

Somun-Kapetanović, R. (2006): Statistics in Economics and Management, University of Sarajevo. Faculty of Economics

Tanović, N. (2011): Identification of medicinal plants of the FB\&H (Final report), Federal Ministrv of Agriculture. Water management and Forestrv. Saraievo

Turtiainen M.. Nuutinen T. (2012): Evaluation of information on wild berrv and mushroom markets in European countries. Small-scale Forestry 11(1): 131145. http://dx.doi.org/10.1007/s11842-011-9173-z.

Vojniković, S., Balić, B., Višnjić, C. (2013): Sustainable use of medicinal, edible and aromatic forest nlants. Facultv of Forestrv Saraievo. (ISBN 978-9958-616-23-5)

Federal Ministrv of Phvsical Planning (2012): Spatial plan of FB\&H 2008-2028. (Available at: http://www.vladatk.kim.ba/) 